\title{
SHORT COMMUNICATION \\ A NEW RECORD OF Carcharhinus leucas IN AN AMAZONIAN RIVER SYSTEM
}

\author{
Leonardo Manir Feitosa ${ }^{1}$, Jorge Luiz Silva Nunes ${ }^{2 *}$ \\ ${ }^{1}$ Laboratório de Dinâmica de Populações Marinhas (DIMAR), Departamento de Pesca e Aquicultura, Universidade \\ Federal Rural de Pernambuco, Recife - PE, Brazil. \\ ${ }^{2}$ Laboratório de Organismos Aquáticos, Departamento de Oceanografia e Limnologia, Universidade Federal do \\ Maranhão, São Luís - MA, Brazil \\ *Corresponding author: silvanunes@yahoo.com
}

\begin{abstract}
RESUMO
Carcharhinus leucas é uma espécie de tubarão cosmopolita que vive em ambientes tropicais e subtropicais. Geralmente são encontradas na maioria dos rios do mundo, mas os seus registros nas bacias hidrográficas amazônicas são escassos. Neste estudo apresentamos um novo registro de uma fêmea juvenil de tubarão cabeça-chata capturada em Cametá (PA) como fauna acompanhante da pesca de espinhel, pesando $8 \mathrm{~kg}$ e medindo $90 \mathrm{~cm}$ de comprimento total. O Litoral Amazônico Brasileiro e os seus sistemas fluviais são alguns dos únicos ambientes onde indivíduos jovens do ano e juvenis podem ser encontrados na região Neotropical do oceano Atlântico. Portanto, estas informações são importantes para delinear futuros estudos sobre o uso de habitat e padrões reprodutivos para a espécie nesta região, uma vez que esta área pode ser crucial para sua conservação desta espécie. Palavras-chave: tubarão cabeça-chata, bacia do rio Tocantins, região Neotropical.

\section{ABSTRACT}

Carcharhinus leucas is a cosmopolitan shark species in tropical and subtropical waters. Normally, individuals are found in most of the major rivers in the world but records in the Amazon basin are somewhat scarce. Here we provide a new record of a young of the year female bull shark caught in Cametá (PA) as bycatch of the bottom longline fishery, weighing $8 \mathrm{~kg}$ and measuring $90 \mathrm{~cm}$ total length. The Brazilian Amazon coast and its freshwater systems are one of the only areas where records of small young of the year and juveniles exist for the Atlantic Ocean on the Neotropical region. Therefore, this information is important to direct future research on habitat use and reproductive patterns for the species in this region, since this could be a crucial area for the species conservation. Keywords: Bull sharks, Tocantins River basin, Neotropical region.
\end{abstract}

Elasmobranchs are mostly marine fishes, but some species can withstand low salinities (e. g. Pristis pristis (Linnaeus, 1758), Carcharhinus leucas (Müller \& Henle, 1839)), or are even obligate freshwater inhabitants (e. g. Potamotrygon spp.) (Grant et al., 2019). Indeed, the species with the most widespread records in freshwater basins in the world is the bull shark, Carcharhinus leucas, which has been found in several tropical and subtropical rivers (Thorson, 1972; Thomerson et al., 1977; Coad et al., 1989; Nicholls, 2017).

The bull shark is considered to be near threatened with extinction by the International Union for the Conservation of Nature (IUCN), but its current population trends are unknown (Simpfendorfer \& Burgess, 2009). However, it is important to notice that species inhabiting both marine and freshwater environments are subjected to a greater interaction with fisheries. In fact, the major threat to C. leucas is fishing (Ferreira et al., 1996; Karl et al., 2011) and possibly dams as a barriers to up and downstream migrations in freshwater systems (Lees et al., 2016; Winemiller et al., 2016). Besides that, this shark species is extremely resilient to habitat modification and extreme environmental conditions (Bangley et al., 2018).

Therefore, records of C. leucas in freshwater systems are important to provide a greater understanding of how this species uses non-marine habitats (Heupel et al., 2010). Many records from the Amazon basin comprise a lot of juvenile bull sharks (Starks, 1913; Thorson, 1972; Ferreira et al., 1996; Feitosa et al., 2016; Goulding et al., 2018), suggesting the region might be an important area 
for this life stage. Thus, these records provide better understanding of how the species uses the Amazon biome's waters, especially since it is an important area in the Atlantic, one of the few parts of the Neotropical region where young of the year and neonates are captured.

The present study aimed at reporting the first capture of a young of the year bull shark in the Tocantins river basin, one of the largest rivers comprising the Amazon region, extending the records of this species in the Amazon River basin. We also provide a review of bull shark records in the Amazon basin based on published and on gray literature review.

The Tocantins River basin is associated with the Araguaia River basin, which together form the Tocantins-Araguaia system corresponding to the second largest drainage in the Amazon, totaling $767,164 \mathrm{~km} 2$ (Ribeiro et al., 1995). It is located in a region with tropical climate, an annual rainfall average of $1,752 \mathrm{~mm}$, and evapotranspiration potential of $768 \mathrm{~mm}$ (Ho et al., 2016). The average river downstream flow near Marabá city, Pará state, is of around $11,000 \mathrm{~m}^{3} \mathrm{~s}^{-1}$ (Ho et al., 2016), and the hydrological regime is defined by rain caused by the Intertropical Convergence Zone (Marengo, 2006; Valverde \& Marengo, 2014).

Additionally, the Tocantins River has been under constant human induced changes from the urban agglomerations (e. g. Cametá city) and mainly for the construction of dams along its course (Akama, 2017). Currently, seven hydroelectric plants operate in the area, with a potential of energy generation up to $11,500 \mathrm{MW}$, the third largest in Brazil (https:// www.ana.gov.br/sala-de-situacao/tocantins/saibamais-tocantins). However, the dams' catchments have been continually experiencing less rainfall, which has both decreased the plants' capacity of energy production and the volume of water flowing on the river (ANA, 2020). These human induced impacts have a profound effect of freshwater fishes. Five other elasmobranchs are known to occur in this river: Paratrygon aiereba (Müller \& Henle, 1841), Paratrygon sp., Potamotrygon henlei (Castelneau, 1855), Potamotrygon motoro (Müller \& Henlei, 1841), and Potamotrygon orbignyi (Castelneu, 1855) (Santos et al., 2004; Lasso et al., 2013), but the impacts of dams and other anthropogenic developments on these species are mostly unknown.
In addition to these freshwater stingrays, the bull shark would be expected to occur in this habitat, although there are no documented records of a shark in this river basin so far.

In 10 August 2019 a young of the year female bull shark was caught in the Cametá municipality, Pará State (Figure 1). The specimen was captured as bycatch of the bottom longline fishery targeting the Gilded catfish (Brachyplatystoma rousseauxii (Castelnau, 1855). Since the only information obtained from this specimen comes from photographic records, video and personal communications with the fishers, no samples from the specimen could be collected. The distance from a general point of capture to the river mouth was calculated using Google Earth Pro software.

Fishers in the Tocantins River caught a young of the year specimen of Carcharhinus leucas weighting $8 \mathrm{~kg}$ and measuring $90 \mathrm{~cm}$ total length (Figure 2). The individual was caught at $6 \mathrm{~m}$ depth and $273 \mathrm{~km}$ away from the estuary in an area with high incidence of small islands. In addition, the capture occurred in the dry season, when freshwater flow decreases, and saltwater intrusion occurs. The local community consumed the fish. Finally, the catch was shared in social media outlets generating a journalistic report by the local media posted on YouTube (https://bit. ly/2mIphUW).

Although commonly encountered in tropical estuaries and rivers, this record represents the first shark ever recorded in the Tocantins River basin. In fact, records of the bull shark in the Amazon basin are scarce. Thorson (1972) provides 20 records for the species in the Amazon River and its tributaries comprising juveniles and adults from both sexes. Werder \& Alhanati (1981) provide three more records of sharks captured well within the river. Further records come from Soto \& Nisa-Castro-Neto (1998), Karl et al. (2011), Gausmann (2018), and a record of a specimen captured in Santarém, Pará state in 2018 (https://glo.bo/31HBxnK). When examining records in the Brazilian Amazon biome on a wider scale, this list increases with records from the Mearim River, Maranhão state (Feitosa et al, 2016), and the present study. Therefore, we consider that there are 29 records of bull shark specimens in the Amazon biome in a span of over 50 years. From those, the vast majority comprise young of the year and juvenile specimens 


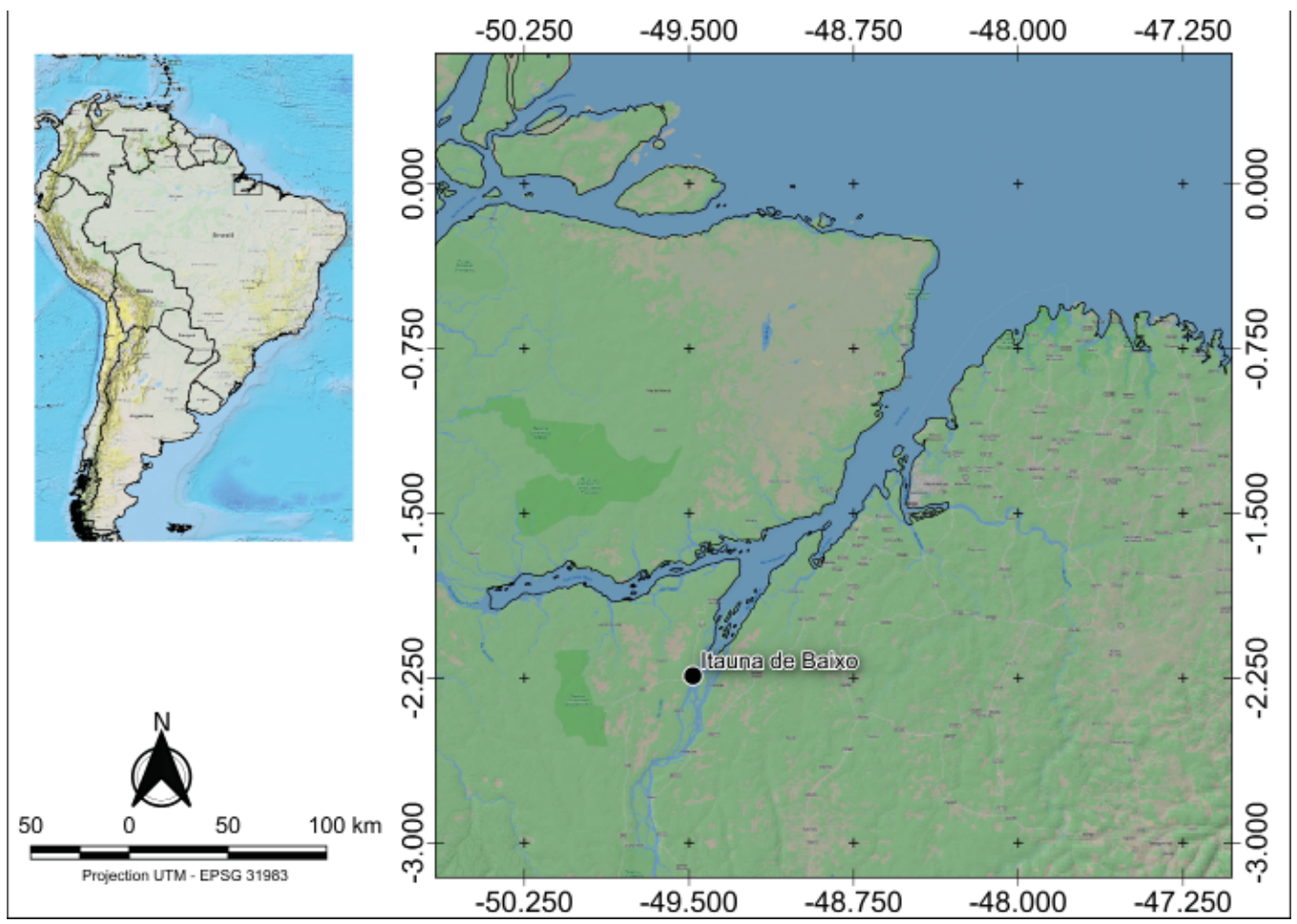

Figure 1. Itauna de Baixo, stretch of the Tocantins River where the specimen of Carcharhinus leucas was captured in Cametá, Pará State, Brazil.

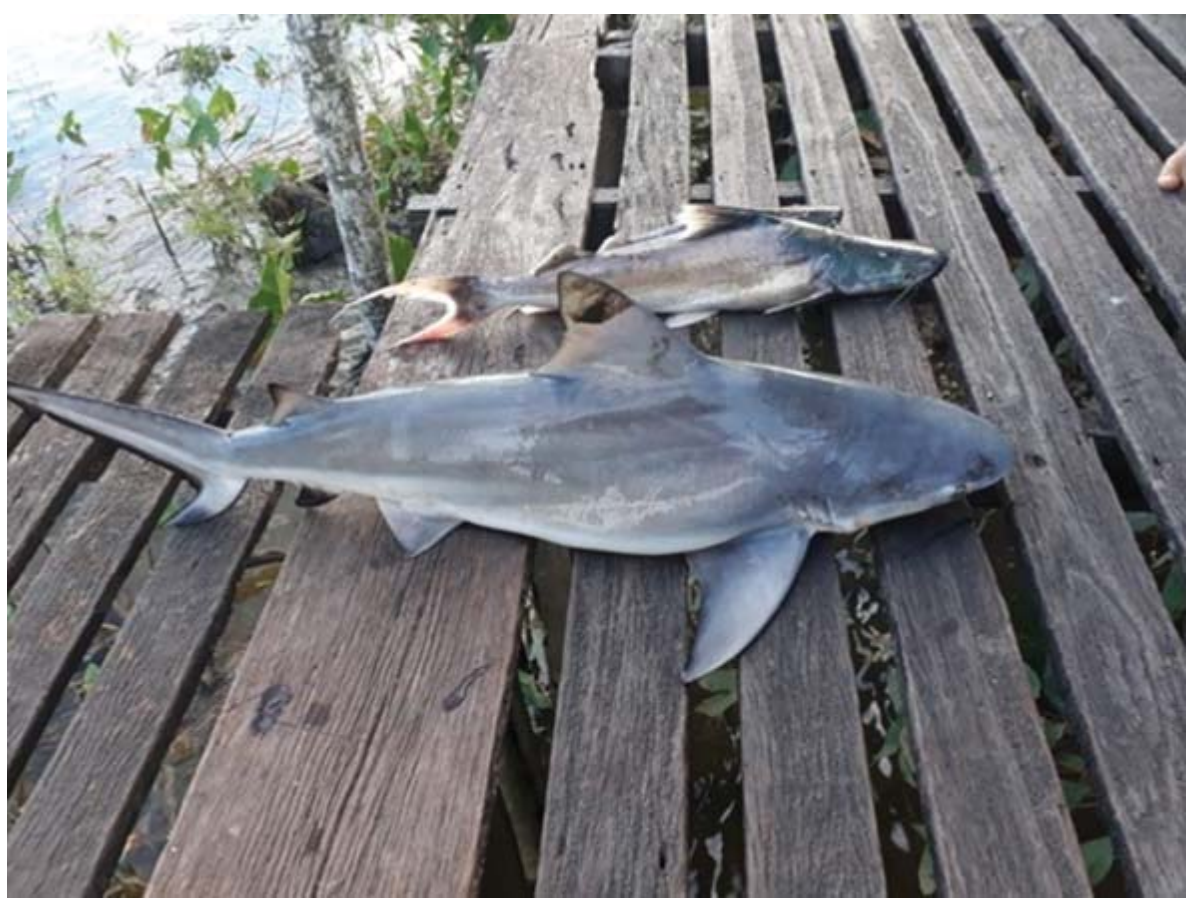

Figure 2. Young of the year female Carcharhinus leucas and Blachyplastytoma rousseauxii specimens captured by fishers in Cametá, Pará state, Brazil. 
Despite the sparse historical record, Brazil's Amazon coast and freshwater systems seem to have the most consistent record of young of the year and juvenile specimens of $C$. leucas. Other records for these life stages in Brazil come from southearstern Brazil (Cananeia, São Paulo) (Sadowsky, 1967), but no recent records exist to our knowledge. Although not enough to support a hypothesis of nursery area.

For $C$. leucas, this information is important to direct future research on habitat use and reproductive patterns for the species in the Amazon biome, including its coastal waters. In fact, this is especially consistent with $C$. leucas behavior, since several rivers in the world are known to be nurseries for this species (Tillet et al., 2011).

Therefore, the existence of a nursery for the bull shark in the Amazon biome must be investigated to better understand this area's role on the species dynamics in the Neotropical region. We also reinforce the need to study the effects of fisheries in its population, since several records also exist from these juveniles on the estuarine area, where intense gillnet and longline fisheries targeting Cynoscion acoupa and Scomberomorus brasiliensis occur (Mourão et al., 2014; Almeida et al., 2014). Furthermore, Alencar et al (2001) provide records of elevated biomass of C. leucas on the Amazon coastal waters, especially near the Amapá state's coast, which is strongly influenced by the Amazon River discharge (Coles et al., 2013). Finally, we suggest employing vertebrae microchemistry to study habitat use and juvenile residency patterns in the area.

\section{ACKNOWLEDGEMENTS}

We thank the journalist Rosângela Gusmão for the information about the bull shark specimen found. We would like to thank Diego Campos for making the map and fishers who posted the record on social networks.

\section{REFERENCES}

AKAMA, A. 2017. Impacts of the hydroelectric power generation over the fish fauna of the Tocantins River, Brazil: Marabá dam, the final blow. Oecol. Aust., 21(3): 222-231.

ALENCAR, C. A. G., SANTANA, J. V. M. \& OLIVEIRA, G. G. 2001. Descrição da pesca de tubarões com espinhel de fundo na região norte do Brasil, durante 1996 e 1997. Arq. Ciênc. Mar., 34: 143-149.
ALMEIDA, Z. S., SANTOS, N. B., CARVALHONETA, R. N. \& PINHEIRO, A. L. 2014. Análise multidisciplinar das pescarias de emalhe da pescadaamarela, de camarão de puçá de muruada e da catação de caranguejo uçá em três municípios costeiros do Maranhão. pp. 161-170. In: M. HAIMOVICI, ANDRIGUETTO FILHO, J. M. \& P. S. SUNYE (Eds.), A Pesca marinha e estuarina no Brasil: estudos de Caso multidisciplinares. Rio Grande: Editora da FURG.

AGÊNCIANACIONAL DE ÁGUAS. Rio Tocantins. Available at: https://www.ana.gov.br/sala-desituacao/tocantins/saiba-mais-tocantins/rio-docesaiba-mais. Accessed in 28 March 2020.

BANGLEY, C. W., PARAMORE, L., SHIFFMAN, D. S. \& RULIFSON, R. A. 2018. Increased Abundance and Nursery Habitat Use of the Bull Shark (Carcharhinus leucas) in Response to a Changing Environment in a Warm-Temperate Estuary. Sci. Rep., 8(1). doi:10.1038/s41598-01824510-z.

AGÊNCIA NACIONAL DE ÁGUAS. Rio Tocantins. Available at: https://www.ana.gov.br/ sala-de-situacao/tocantins/saiba-mais-tocantins/riodoce-saiba-mais. Accessed in 28 March 2020.

BANGLEY, C. W., PARAMORE, L., SHIFFMAN, D. S. \& RULIFSON, R. A. 2018. Increased Abundance and Nursery Habitat Use of the Bull Shark (Carcharhinus leucas) in Response to a Changing Environment in a Warm-Temperate Estuary. Sci. Rep., 8(1). doi:10.1038/s41598-01824510-z

COAD, B. W. \& AL-HASSAN, L. A. J. 1989. Freshwater shark attacks at Basrah, Iraq. Zool. Middle East, 3(1): 49-54. doi:10.1080/09397140 .1989 .10637574

COLES, V. J., BROOKS, M. T., HOPKINS, J., STUKEL, M. R., YAGER, P. L. \& HOOD, R. R. 2013. The pathways and properties of the Amazon River Plume in the Tropical North Atlantic Ocean.

J. Geophys. Res. Oceans, 118: 6894-6913. doi: 10.1002/2013JC008981

FEITOSA, L. M., MARTINS, A. P. B. \& NUNES, J. L. S. 2016. New record of Carcharhinus leucas (Valenciennes, 1839) in an equatorial river system. Mar. Biodivers. Rec. 9(1). doi:10.1186/s41200016-0094-6

FERREIRA, E. J. G., ZUANON, J. \& DOS SANTOS, G. M. 1996. A list of commercial fish 
species from Santarem, State of Para, Brazil. Naga, the ICLARM Quarterly, 19(3), pp. 41-44.

GAUSMANN, P. 2018. Synopsis of global freshwater occurrences of the bull shark (Carcharhinus leucas Valenciennes 1839, Carcharhinidae) with comments on the geographical range. Unpublished report.

GOULDING, M., VENTICINQUE, E., RIBEIRO, M. L. DE B., BARTHEM, R. B., LEITE, R. G., FORSBERG, B., ... CAÑAS, C. 2018. Ecosystembased management of Amazon fisheries and wetlands. Fish Fish., doi:10.1111/faf.12328

GRANT, M. I., KYNE, P. M., SIMPFENDORFER, C. A., WHITE, W. T. \& CHIN, A. 2019. Categorising use patterns of non-marine environments by elasmobranchs and a review of their extinction risk. Rev. Fish Biol. Fisher., doi:10.1007/s11160-01909576-w

HEUPEL, M. R., YEISER, B. G., COLLINS, A. B., ORTEGA, L. \& SIMPFENDORFER, C. A. 2010. Long-term presence and movement patterns of juvenile bull sharks, Carcharhinus leucas, in an estuarine river system. Mar. Freshwater Res., 61(1): 1, doi:10.1071/mf09019

HO, J. T., THOMPSON, J. R. \& BRIERLEY, C. 2016. Projections of hydrology in the TocantinsAraguaia Basin, Brazil: uncertainty assessment using the CMIP5 ensemble. Hydrolog. Sci. J., 61(3): 551-567. doi:10.1080/02626667.2015.1057513

KARL, S. A., CASTRO, A. L. F., LOPEZ, J. A., CHARVET, P. \& BURGESS, G. H. 2010. Phylogeography and conservation of the bull shark (Carcharhinus leucas) inferred from mitochondrial and microsatellite DNA. Conserv. Genet., 12(2): 371-382. doi:10.1007/s10592-010-0145-1

LASSO, C. A., ROSA, R. S., SÁNCHEZDUARTE, P., MORALES-BETANCOURT, M. A. \& AGUDELO-CÓRDOBA, E. 2013. Rayas de agua dulce (Potamotrygonidae) de Suramérica. Parte I. Colombia, Venezuela, Ecuador, Perú, Brasil, Guyana, Surinam y Guayana Francesa: diversidad, bioecología, uso y conservación. Serie Recursos Hidrobiológicos y Pesqueros Continentales de Colombia. Bogotá: Instituto de Investigación de Recursos Biológicos Alexander von Humboldt. 368p.

LEES, A. C., PERES, C. A., FEARNSIDE, P. M., SCHNEIDER, M. \& ZUANON, J. A. S. 2016. Hydropower and the future of Amazonian biodiversity. Biodivers. Conserv., 25(3): 451-466. doi:10.1007/s10531-016-1072-3

MARENGO, J. A. 2006. On the Hydrological Cycle of the Amazon Basin: a historical review and current state-of-the-art. Rev. Bras. de Meteorol., 21 (3): $1-19$,

MOURÃO, K. R. M., ESPÍRITO-SANTO, R. V., SILVA, B. B., ALMEIDA, M. C., ISAAC, V. J., FRÉDOU, T. \& FRÉDOU, F. L. 2014. A pesca de Scomberomorus brasiliensis e alternativas para o seu manejo no litoral nordeste do Pará - Brasil. pp. 171-180. In: M. HAIMOVICI, ANDRIGUETTO FILHO, J. M. \& P. S. SUNYE (Eds.), A Pesca marinha e estuarina no Brasil: estudos de Caso multidisciplinares. Rio Grande: Editora da FURG.

NICHOLLS, Z. W. 2017. The Bull Shark Compendium. Deep Sea Publishing,

RIBEIRO, M.C.L.B; PETRERE-JR., M. \& JURAS, A.A. 1995. Ecological integrity and fisheries ecology of the Araguaia-Tocantins river basin, Brazil. Regul. Rivers Res. Manage., 11: 325-350. doi:10.1002/ rrr.3450110308

SADOWSKY, V. 1971. Notes on the Bull shark Carcharhinus leucas in the lagoon region of Cananéia, Brazil. Bol. Inst. Oceanogr., 20(2): 71-78. doi:10.1590/s0373-55241971000200002

SANTOS, G. M.; JURAS, A. A.; MERONA, B. \& JEGU, M. 2004. Peixes do baixo Rio Tocantins. 20 anos depois da Usina Hidrelétrica Tucuruí. Brasilia: Eletronorte.

SIMPFENDORFER, C. \& BURGESS, G. H. 2009. Carcharhinus leucas. The IUCN Red List of Threatened Species: e.T39372A10187195. https://dx.doi.org/10.2305/IUCN.UK.20092.RLTS. T39372A10187195.en Accessed in February 4th 2020.

SOTO, J. M. R. \& NISA-CASTRO-NETO, W. 1998. Revisão dos registros de tubarão touro, Carcharhinus leucas (Valenciennes, 1839) (Chondrichthyes, Carcharhinidae), em rios e lagunas brasileiras. pp 314-316.In: Resumos Expandidos da 11a Semana Nacional de Oceanografia. FURG, Rio Grande: FURG.

STARKS, E. C. 1913. The fishes of the Stanford Expedition to Brazil. Stanford Univ. Publ., Univ. Ser. 1913(12):4.

THOMERSON, J.E., THORSON, T.B. \& HEMPEL, R.L. 1977. The Bull Shark, Carcharhinus leucas, from the Upper Mississippi River near Alton, Illinois. 
Copeia, 1977(1): 166. doi:10.2307/1443522

THORSON, T.B. 1972. The Status of the Bull Shark, Carcharhinus leucas, in the Amazon River. Copeia, 1972(3): 601. doi:10.2307/1442947

TILLETT, B. J., MEEKAN, M. G., PARRY, D., MUNKSGAARD, N., FIELD, I. C., THORBURN, D. \& BRADSHAW, C. J. 2011. Decoding fingerprints: elemental composition of vertebrae correlates to agerelated habitat use in two morphologically similar sharks. Mar. Ecol. Prog. Ser., 434: 133-142. doi: 10.3354/meps09222

VALVERDE, M. \& MARENGO, J. 2014. Extreme
Rainfall Indices in the Hydrographic Basins of Brazil. Open J. Modern Hydrology., 4: 10-26.doi: 10.4236/ ojmh.2014.41002.

WERDER, U. \& ALHANATI, C. E. 1981. Informe sobre um tubarão (Carcharhinus leucas), capturado no Amazonas com alguns detalhes de sua morfologia externa. Acta Amaz., 11(1): 139-196.

WINEMILLER, K. O., MCINTYRE, P. B., CASTELlO, L., FLUET-CHOUINARD, E., GIARRIZZO, T., NAM, S., ... SAENZ, L. 2016. Balancing hydropower and biodiversity in the Amazon, Congo, and Mekong. Science, 351(6269): 128-129. doi:10.1126/science.aac7082 